\title{
Benign prostatic hyperplasia: laser prostatectomy (PVP)
}

\section{HIPERPLASIA PROSTÁTICA BENIGNA: PROSTATECTOMIA POR VAPORIZAÇÃo A LASER (PVP)}

\author{
Authorship: Brazilian Society of Urology \\ Participants: Nunes $R^{2} V^{1}$, Oliveira RRM ${ }^{1}$, Carneiro $A^{1}$, Neto $A M^{1}$, Antunes $A A^{1}$, \\ Wanderley Marques Bernardo², Antônio Silvinato ${ }^{2}$
}

Final draft: September $3^{\text {rd }}, 2016$

\author{
${ }^{1}$ Sociedade Brasileira de Urologia (SBU) \\ ${ }^{2}$ Associação Médica Brasileira (AMB)
}

The Guidelines Project, an initiative of the Brazilian Medical Association, aims to combine information from the medical field in order to standardize procedures to assist the reasoning and decision-making of doctors.

The information provided through this project must be assessed and criticized by the physician responsible for the conduct that will be adopted, depending on the conditions and the clinical status of each patient.

\section{Grades of Recommendation And LeVels OF EVIDENCE}

- A: Experimental or observational studies of higher consistency.

- B: Experimental or observational studies of lower consistency.

- C: Cases reports (non-controlled studies).

- D: Opinion without critical evaluation, based on consensus, physiological studies or animal models.

\section{Овjective}

The objective of this guideline is to present the main available evidence comparing transurethral resection of the prostate with laser prostatectomy (PVP) in patients with benign prostatic hyperplasia (BPH) in relation to the main peri- or postoperative outcomes, allowing the formalization of recommendations directly supported by such evidence.

\section{Description OF EVIDENCE COLLECTION METHOD}

This guideline followed the standard of a systematic review with evidence retrieval based on the EBM (evidence-based medicine), so that clinical experience is integrated with the ability to critically analyze and apply scientific information rationally, thus improving the quality of medical care. EBM uses existing and currently available scientific evidence, with good internal and external validity for the application of its results in clinical practice. ${ }^{1,2}$

Systematic reviews are currently considered the level I of evidence for any clinical question by systematically summarizing information on a particular topic through primary studies (clinical trials, cohort studies, case-control or cross-sectional studies) using a reproducible methodology, in addition to integrating information on effectiveness, efficiency, efficacy and safety. ${ }^{1,2}$

We use the structured mode of formulating the question synthesized by the acronym PICO, where P stands for patient or population presenting prostatic hyperplasia, I stands for intervention with laser prostatectomy (PVP), C stands for comparison with transurethral resection of the prostate and $\mathrm{O}$ stands for the outcome of efficacy and harm. Based on the structured question, we identified the descriptors that formed the basis of the search for evidence in the following databases: Medline, Embase, Central Cochrane, Cochrane Library. Thus, 367 studies were retrieved, and, after applying the eligibility criteria (inclusion and exclusion), 11 were selected to answer the clinical question (Annex I).

\section{Clinical question}

What is the effectiveness of laser prostatectomy (PVP) in patients with benign prostatic hyperplasia?

\section{INTRODUCTION}

Benign prostatic hyperplasia (BPH) is a common disease with high morbidity in the elderly. Patients with urinary symptoms, mainly obstructive, may require surgical treatment, which is usually performed through transurethral resection of the prostate (conventional TURP). Complications of the procedure include bleeding, TURP syndrome (water intoxication), urinary incontinence, 
urinary retention and sexual dysfunction, especially regarding ejaculation function.

In an attempt to reduce morbidity, the development of new alternative surgical procedures has been encouraged, including photoselective vaporization of the prostate (PVP) using laser.

The laser emits light at a wavelength of $532 \mathrm{~nm}$, which will be absorbed by hemoglobin, leading to heating of the prostatic tissue. In the beginning, PVP was performed with potassium-titanyl-phosphate (KTP) laser at $60 \mathrm{~W}$ and later at $80 \mathrm{~W}$. Then, laser prostatectomy (PVP) using a high-performance system (HPS) $120 \mathrm{~W}$ laser or XPS $180 \mathrm{~W}$ laser was introduced, aiming at reducing the limitations of KTP, as well as improving results compared with conventional TURP.

The goal is to reduce hospitalization time, bleeding, and other complications, but there is some doubt as to the effectiveness of laser treatment with regard to the replacement of conventional TURP as a first-line treatment.

\section{Selected eVidence Results}

Patients (> 50 years) with urinary flow (UF) $\leq 15 \mathrm{~mL} / \mathrm{s}$; prostate symptoms score (IPSS) $\geq 12$; prostatic volume (PV): $15-85 \mathrm{~cm}^{3}$ (USG); obstruction (AG nomogram) (N: 76), were treated with PVP using KTP $80 \mathrm{~W}$ laser and star pulse quasicontinuous wave laser (laserscope) emitting green light at a wavelength of $532 \mathrm{~nm}(\mathrm{~N}: 38)$ compared with transurethral resection of the prostate (conventional TURP) $(\mathrm{N}: 38)$, with the following outcomes being assessed: urinary flow, international prostate symptoms score (IPSS), quality of life score (QoL), bother score, postvoid residual volume (PVRV), surgical time, $\mathrm{PO} \mathrm{Hb}$, length of catheterization and length of hospitalization after 6 weeks and at 3, 6 and 12-month follow-up. The use of laser leads to significant increase in UF $(\mathrm{mL} / \mathrm{s})$, decline in IPSS, increase in quality of life (QoL), increase in bother score, increase in postvoid residual volume (PVRV) $(\mathrm{mL})$, shorter bladder irrigation time ( $\mathrm{min}$ ) and shorter length of hospitalization (days), and less decrease in hemoglobin levels $(\mathrm{g} / \mathrm{dL})$. There is no difference in surgical time (min). ${ }^{3}(\mathbf{B})$

In patients aged 68 years, $\mathrm{BPH}$; PV: 70 to $100 \mathrm{~mL}$; UF < $15 \mathrm{~mL} / \mathrm{s}$; PVRV > 150 mL; IPSS > 7 (N: 76), PVP with KTP/532 high-power laser emitting green light (80W) (N:39) was compared with transurethral resection of the prostate (conventional TURP) (N: 37), and the following outcomes were assessed: IPSS and IIEF-5 scores; PV; PVRV; UF; urinary retention; transfusion; re-intervention after 6 months. There was a significant benefit with the use of PVP laser in relation to all analyzed outcomes; however, there was an increased risk of urinary retention (NNH: 8$)$ and reintervention (NNH: 6). ${ }^{4}$ (B)
Patients with BPH; IPSS > 16; UF < 15 mL/s; PV < 100 $\mathrm{mL}$; PVRV < $100 \mathrm{~mL}$ (N: 120) treated with HPS 120-W laser using lithium triborate (LBO) crystal, producing 532-nm waves (N: 60) or transurethral resection of the prostate (conventional TURP) (N: 60) were assessed regarding surgical time; $\mathrm{Hb}$; transfusion; length of catheterization; length of hospitalization; complications; IPSS; PVRV; PV; UF at 1, 3, $6,12,24$ and 36 months. The use of laser compared with conventional TURP significantly increased the outcome of surgical time, but reduced the outcomes of bleeding, length of catheterization and length of hospitalization. There is a decline in the risk of transfusions (NNT: 6) and intraoperative complications (NNT: 5), but also an increase in the number of early (NNH: 2) and late (NNH: 8) complications. ${ }^{5}$ (B)

PVP treatment using HPS $120-\mathrm{W}$ laser in 50 patients was compared with transurethral resection of the prostate (conventional TURP) in other 50 patients, the following inclusion criteria being adopted: BPH; IPSS > 15; $\mathrm{PV}<80 \mathrm{~cm}^{3}$; urinary flow $<15 \mathrm{~mL} / \mathrm{s}$. At 1, 3, 6, 12 and 24 months, the following outcomes were assessed: IPSS; urinary flow; surgical time; $\mathrm{Hb}$; transfusion; complications; length of hospitalization; length of catheterization. The results of laser intervention reduced blood loss, length of catheterization and length of hospitalization compared with conventional TURP. Nevertheless, they increased surgical time. Regarding catheterization with a probe $<20$ $\mathrm{Fr}$, intraoperative and late complications, there is a benefit to using laser with $\mathrm{NNT}=1,10$ and 6 , respectively. ${ }^{6}(\mathbf{B})$

In patients with $\mathrm{BPH}$; $>50$ years; IPSS $\geq 12$ and bother score $\geq 3$; $\mathrm{Qmax}<12 \mathrm{~mL} / \mathrm{s}$; prostatic volume between $25 \mathrm{~mL}$ and $80 \mathrm{~mL} ; \mathrm{PVRV}<300 \mathrm{~mL}(\mathrm{~N}: 139)$, two treatment modalities were compared: PVP HPS $120-\mathrm{W}$ laser (N: 69) and transurethral resection of the prostate (conventional TURP) (N: 70) based on IPSS; length of hospitalization; Qmax; PVRV; complications; sexual symptoms; quality of life at 12 months. Only surgical time was shorter using laser treatment, while none of the other outcomes presented significant differences, although length of hospitalization was shorter with conventional TURP. ${ }^{7}$ (B)

Bleeding (measured by $\mathrm{Hb}$ ) and length of catheterization were less noticeable in 64 patients with BPH (age > 50 years; IPSS > 7; prostatic volume > 20 and < $80 \mathrm{cc}$; urinary flow (Q max) $<15 \mathrm{~mL} / \mathrm{s}$ ) treated with PVP (laser emitting green light at a wavelength of $532 \mathrm{~nm}, 30$ to $80 \mathrm{~W})$ compared with 64 patients treated with conventional TURP, at 12-month follow-up. Nevertheless, surgical time was longer in the group treated with PVP. ${ }^{8}(\mathbf{B})$

In patients with lower urinary tract symptoms due to BPH (N: 20) treated with PVP HPS 120-W laser) or transurethral resection of the prostate (conventional 
TURP), there is no difference between the two treatment modalities regarding outcomes expressed by IPSS, IIEF-5 and ICIQ-SF scores, or the following measures: PVRV and Qmax, at 12-month follow-up. ${ }^{9}$ (B)

In patients with BPH, IPSS > 15, treatment failure, Qmax $<15 \mathrm{~mL} / \mathrm{s}$ and prostatic volume $<100 \mathrm{~mL}(\mathrm{~N}: 200)$, comparison between PVP (HPS with 80-W KTP laser) (N: 100) and transurethral resection of the prostate (conventional TURP) (N: 100) made it possible to assess the outcomes of length of catheterization, length of hospitalization, periand postoperative complications, IPSS and QoL, Qmax, PVRV and prostatic volume, at 1, 3, 6, 12, 24 and 36-month follow-up. The outcomes measured at 24 months did not present significant difference between the two treatment modalities in relation to the scores: quality of life (QoL), IPSS, urinary flow, PVRV and PO Hb. But there was significant benefit in favor of the laser in the following outcomes: prostatic volume, length of catheterization and length of hospitalization. Conventional TURP yielded a shorter surgical time. Regarding complications, there was a decline in the rate of transfusion and perforation of the prostatic capsule with the use of the laser..$^{10}(\mathbf{B})$

Patients with BPH and moderate or severe lower urinary tract symptoms (IPSS $>16$ ), therapeutic failure, maximum flow rate $(\mathrm{Qmax})<15 \mathrm{~mL} / \mathrm{s}$, PVRV $>100 \mathrm{~mL}$ and prostatic volume $<100 \mathrm{~mL}$ (N: 62) were treated comparatively with PVP (HPS 180-W laser) (N: 31) and transurethral resection of the prostate (conventional TURP) (N:31). At the 12-month follow-up, surgical time was longer using laser, but the lengths of hospitalization and catheterization were shorter, with lower rates of transfusion (NNT: 5) and perforation (NNT: 6). The other outcomes did not differ: hemoglobin and transfusion, other peri- and postoperative complications, IPSS, QoL, Qmax, PVRV and prostatic volume. ${ }^{11}(\mathbf{B})$

Except for a shorter length of hospitalization, the treatment of patients with symptoms of BPH obstruction; 64 years; IPSS > 7; Qmax < $15 \mathrm{~mL} / \mathrm{s}$; prostatic volume < $80 \mathrm{~mL}$; PVRV > $150 \mathrm{~mL}$ (N: 124) with PVP 120-W laser (N: 60), compared with transurethral resection of the prostate (conventional TURP) (N: 64), failed to demonstrate superiority or inferiority when analyzed in relation to the following outcomes: IPSS; length of hospitalization; Qmax; PVRV; complications; sexual symptoms; re-intervention or transfusion at 24 months. ${ }^{12}$ (B)

In patients with lower urinary tract symptoms due to BPH with obstruction; aged 40 to 80 years; IPSS $\geq 12$; Qmax $<15 \mathrm{~mL} / \mathrm{s}$; prostatic volume $\leq 100 \mathrm{~mL}(\mathrm{~N}: 281)$, there was no difference between treatment with transurethral resection of the prostate (conventional TURP) (N: 142 ) and PVP with 180-W XPS laser vaporization (N: 139), at 24 months, regarding the following outcomes: quality of life (QoL); IPSS; urinary flow (mL/s); PVRV; prostatic volume; re-treatment and complications. ${ }^{13}(\mathbf{B})$

\section{EVIDENCE SUMmARY}

There is evidence, with high risk of bias, of the benefit of laser prostatectomy (PVP) in patients with $\mathrm{BPH}$ compared to conventional TURP regarding UF, IPSS, QoL, bother score, IIEF-5 score, postvoid residual volume (PVRV), bladder irrigation/length of catheterization, length of hospitalization (days), $\mathrm{Hb}$ decline, prostatic volume, urinary retention, transfusion (NNT: 6), re-intervention (?), intraoperative complications (NNT: 5), early (NNT: 10) and late (NNT: 6) complications at different times, from 6 to 24 months.

There is evidence, with the same high risk of bias, of lower PVP benefit compared to conventional TURP regarding risk of urinary retention (NNH: 8), re-intervention (NNH: 6), surgical time, number of early (NNH: 2) and late (NNH: 8) complications, as well as length of hospitalization.

There is no difference between the two treatment modalities in relation to the outcomes expressed by the scores: IPSS, IIEF-5 and ICIQ-SF, or the following measurements: urinary flow, PVRV, prostatic volume and Qmax, length of hospitalization, complications, sexual symptoms, re-intervention, need for transfusion or re-treatment at 12 to 24 months of follow-up.

\section{Recommendation}

Due to controversies regarding the superiority or inferiority of treatment of benign prostatic hyperplasia using laser PVP compared to transurethral resection, it is not possible to recommend treatment with PVP instead of conventional TURP. (C)

\section{Conflict of Interest}

The authors declare no conflict of interest.

\section{References}

1. Nobre MR, Bernardo WM, Jatene FB. A prática clínica baseada em evidências. Parte I - Questões clínicas bem construídas. Rev Assoc Med Bras. 2003; 49(4):445-9.

2. Bernardo WM, Nobre MR, Jatene FB. A prática clínica baseada em evidências. Parte II - Questões clínicas bem construídas. Rev Assoc Med Bras. 2004; 50(1):104-8.

3. Bouchier-Hayes DM, Anderson P, Van Appledorn S, Bugeja P, Costello AJ. KTP laser versus transurethral resection: early results of a randomized trial. J Endourol. 2006; 20(8):580-5.

4. Horasanli K, Silay MS, Altay B, Tanriverdi O, Sarica K, Miroglu C. Photoselective potassium titanyl phosphate (KTP) laser vaporization versus transurethral resection of the prostate for prostates larger than $70 \mathrm{~mL}$ : a short-term prospective randomized trial. Urology. 2008; 71(2):247-51.

5. Al-Ansari A, Younes N, Sampige VP, Al-Rumaihi K, Ghafouri A, Gul T, et al. GreenLight HPS 120-W laser vaporization versus transurethral resection of the prostate for treatment of benign prostatic hyperplasia: a randomized clinical trial with midterm follow-up. Eur Urol. 2010; 58(3):349-55. 
6. Capitán C, Blázquez C, Martin MD, Hernández V, de la Peña E, Llorente C. GreenLight HPS 120-W laser vaporization versus transurethral resection of the prostate for the treatment of lower urinary tract symptoms due to benign prostatic hyperplasia: a randomized clinical trial with 2-year follow-up. Eur Urol. 2011; 60(4):734-9.

7. Lukacs B, Loeffler J, Bruyère F, Blanchet $\mathrm{P}$, Gelet A, Coloby P, et al. ; REVAPRO Study Group. Photoselective vaporization of the prostate with GreenLight 120-W laser compared with monopolar transurethral resection of the prostate: a multicenter randomized controlled trial. Eur Urol. 2012; 61(6):1165-73.

8. Mohanty NK, Vasudeva P, Kumar A, Prakash S, Jain M, Arora RP. Photoselective vaporization of prostate vs. transurethral resection of prostate: a prospective, randomized study with one year follow-up. Indian J Urol. 2012; 28(3):307-12.

9. Pereira-Correia JA, de Moraes Sousa KD, Santos JB, de Morais Perpétuo D, Lopes-da-Silva LF, Krambeck RL, et al. GreenLight HPS ${ }^{\mathrm{TM}} 120$-W laser vaporization vs transurethral resection of the prostate $(<60 \mathrm{~mL})$ : a 2-year randomized double-blind prospective urodynamic investigation. BJU Int. 2012; 110(8):1184-9.

10. Xue B, Zang Y, Zhang Y, Yang D, Gao J, Sun C, et al. GreenLight HPS 120W laser vaporization versus transurethral resection of the prostate for treatment of benign prostatic hyperplasia: a prospective randomized trial. J Xray Sci Technol. 2013; 21(1):125-32.

11. Jovanović M, Džamić Z, Aćimović M, Kajmaković B, Pejčić T. Usage of GreenLight HPS 180-W laser vaporisation for treatment of benign prostatic hyperplasia. Acta Chir Iugosl. 2014; 61(1):57-61.

12. Telli O, Okutucu TM, Suer E, Burgu B, Gulpinar O, Yaman O, et al. A prospective, randomized comparative study of monopolar transurethral resection of the prostate versus photoselective vaporization of the prostate with GreenLight 120-W laser, in prostates less than $80 \mathrm{cc}$. Ther Adv Urol. 2015; 7(1):3-8.

13. Thomas JA, Tubaro A, Barber N, d'Ancona F, Muir G, Witzsch U, et al. A multicenter randomized noninferiority trial comparing GreenLight-XPS laser vaporization of the prostate and transurethral resection of the prostate for the treatment of benign prostatic obstruction: two-yr outcomes of the GOLIATH Study. Eur Urol. 2016; 69(1):94-102.

14. Jadad AR, Moore RA, Carroll D, Jenkinson C, Reynolds DJ, Gavaghan DJ, et al. Assessing the quality of reports of randomized clinical trials: is blinding necessary? Control Clin Trials. 1996; 17(1):1-12.

15. Goldet G, Howick J. Understanding GRADE: an introduction. J Evid Based Med. 2013; 6(1):50-4.

16. Wells G, Shea B, O'Connell D, Robertson J, Peterson J, Welch V, et al. The Newcastle-Ottawa Scale (NOS) for assessing the quality of nonrandomised studies in meta-analyses. Eur J Epidemiol. 2011; 25:603-5.

17. Levels of Evidence and Grades of Recommendations - Oxford Centre for Evidence Based Medicine. Available from: http://cebm.jr2.ox.ac.uk/docs/ old_levels.htm.

\section{Annex I}

\section{Clinical question}

What is the effectiveness of laser prostatectomy (PVP) in patients with benign prostatic hyperplasia?

\section{Structured question}

- P: Prostatic hyperplasia

- I: Laser prostatectomy (photoselective vaporization of the prostate [PVP])

- C: Transurethral resection of the prostate

- O: Effectiveness and harm

\section{Search strategy}

- \#1 - (Prostatic Hyperplasia OR Prostatic Hypertrophy OR Prostatic Adenoma)
- \#2 - (Laser Therapy OR Laser OR Lasers OR Greenlight)

- \#3-Random*

- \#4 - Systematic[sb]

$1^{\text {st }}$ RETRIEVAL $=(\# 1$ AND \#2 AND \#3) OR $(\# 1$ AND \#2 AND \#4) $=367$

((Prostatic Hyperplasia OR Prostatic Hypertrophy OR Prostatic Adenoma) AND (Laser Therapy OR Laser OR Lasers OR Greenlight) AND Random*)) OR ((Prostatic Hyperplasia OR Prostatic Hypertrophy OR Prostatic Adenoma) AND (Laser Therapy OR Laser OR Lasers OR Greenlight) AND Systematic[sb]))

\section{Articles retrieved}

The obtaining of evidence to be used to analyze the clinical question followed the steps of: elaboration of the clinical question, structuring of the question, search for evidence, critical evaluation and selection of evidence, presentation of results and recommendations.

The bases of scientific information consulted were: Medline via Pubmed, Embase, Central Cochrane and Cochrane Library.

A total of 367 articles were retrieved, of which 22 were selected after reading the title and abstract; of these 11 had the full text accessed to answer the proposed clinical question (Table 1)..$^{3-13}$

\section{Inclusion and exclusion criteria}

Phase III randomized controlled clinical trials, systematic reviews (with or without meta-analyzes), comparative (or non-comparative) studies were included, and, in their absence, the best evidence available to answer the clinical question within the limits of PICO.

\section{According to study design}

Narrative reviews, case reports, case series, studies presenting preliminary results only were, in principle, excluded from the selection. Systematic reviews and meta-analyzes were used with the principle of retrieving references that may have been lost since the initial search strategy. Controlled clinical trials were assessed based on the Jadad ${ }^{14}$ and GRADE $^{15}$ scores.

\section{Language}

We included studies available in Portuguese, English or Spanish.

\section{According to type of publication}

Only full-text studies were considered for critical assessment. 


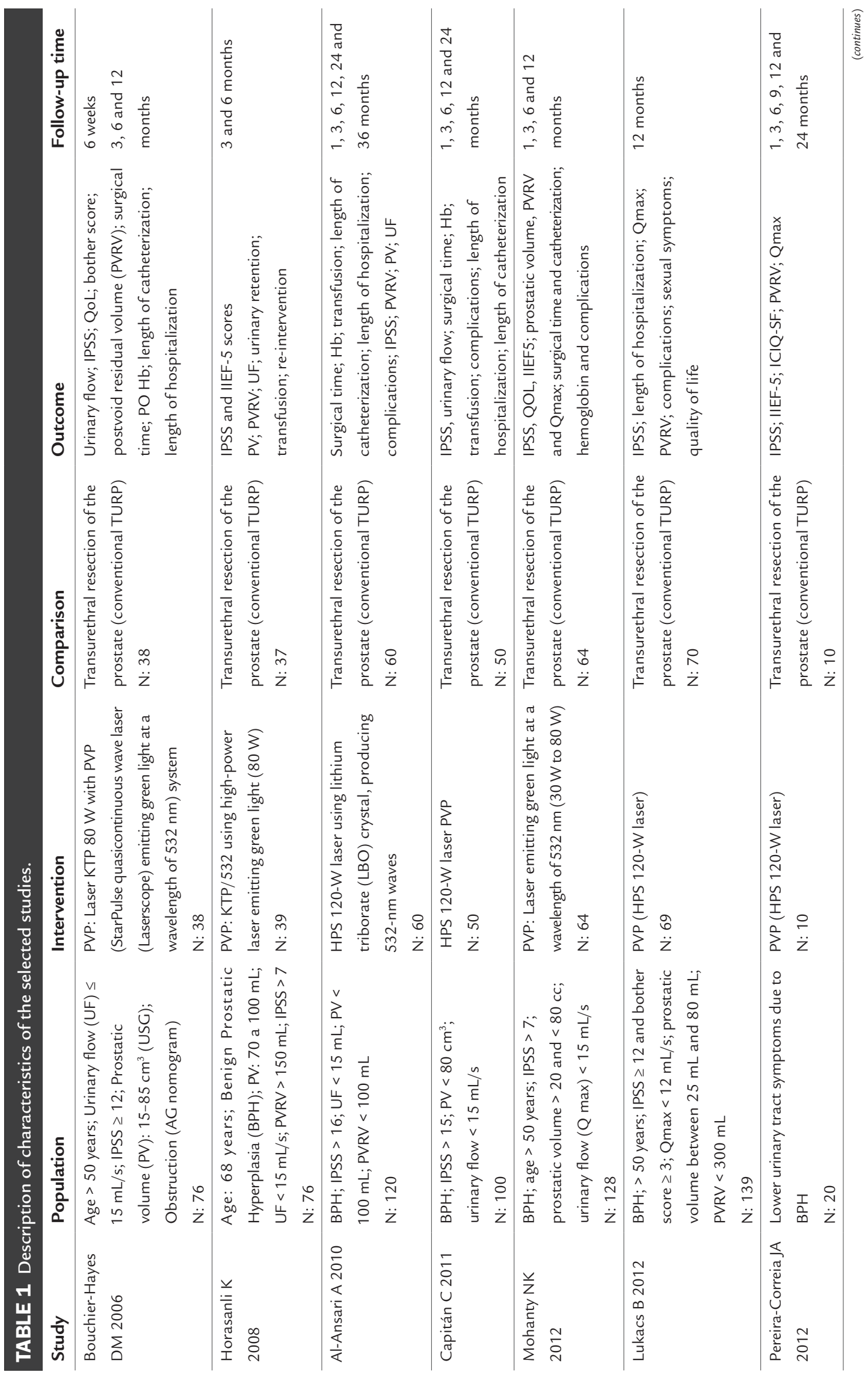




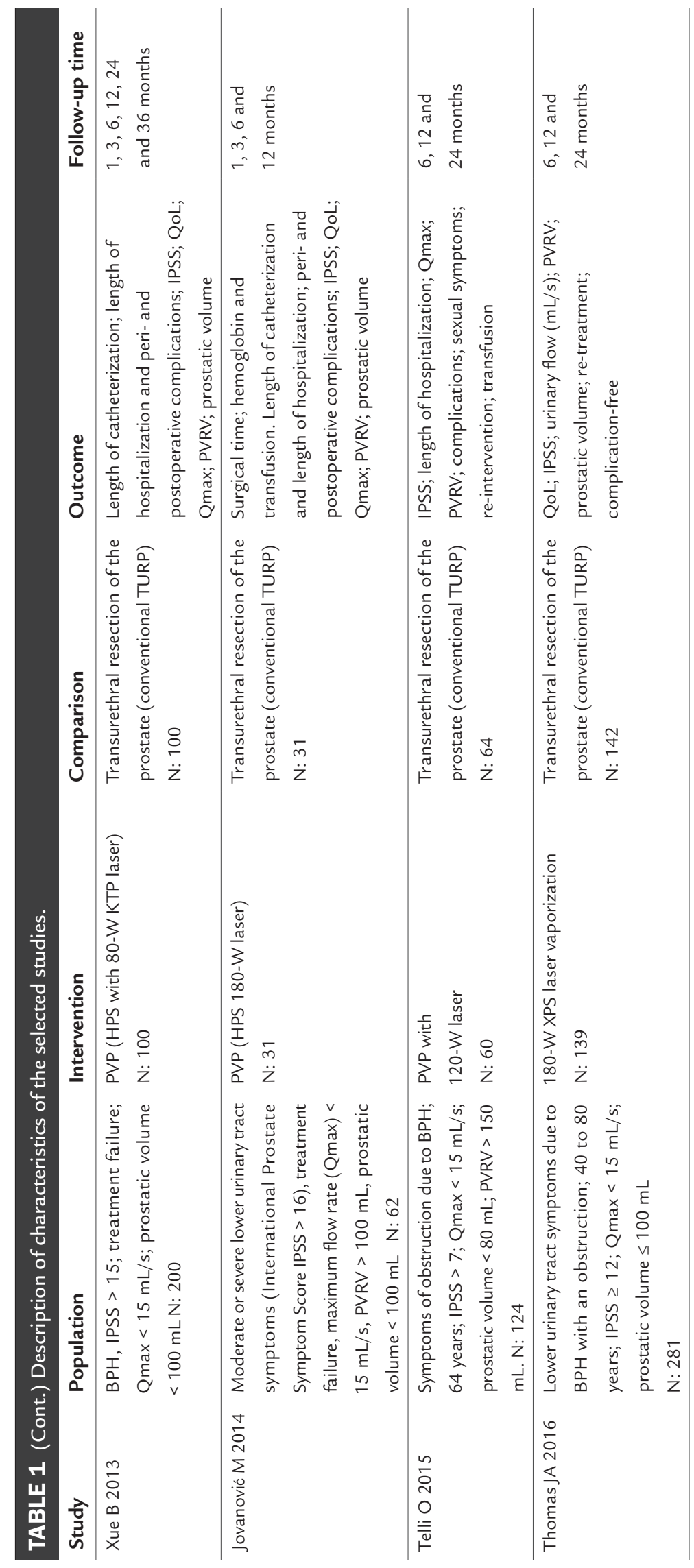




\section{Critical appraisal method}

After applying the inclusion and exclusion criteria, whenever the selected evidence was defined as a randomized controlled trial (RCT), an appropriate Critical Assessment Checklist was applied (Table 2). The critical evaluation of the RCT allows classification according to the Jadad score, ${ }^{14}$ so that Jadad < three (3) trials are considered inconsistent (grade B), while those scoring $\geq$ three (3) are found consistent (grade
A), and according to the GRADE classification ${ }^{15}$ (strong or moderate evidence).

If the selected evidence was defined as a comparative study (observational cohorts or non-randomized clinical trial), an appropriate critical evaluation check-list was applied (Table 3), allowing the classification of the study according to the New Castle Otawa Scale, ${ }^{16}$ so that cohort studies presenting a score $\geq 6$ would be consistent, while those scoring $<6$ would be inconsistent.

\section{TABLE 2 Script for critical evaluation of randomized controlled clinical trials.}

\section{Study data}

References, study design, Jadad, strength of evidence

Patient selection

\section{Sample calculation}

Estimated differences, power, level of significance, total of patients

\section{Patients}

Recruited, randomized, prognostic differences

\section{Patient follow-up}

Time, losses, migration

\section{Analysis}

Intention to treat, analyzed, intervention and control

\section{Result}

Benefit or harm in absolute data, mean benefit or mean harm

\section{TABLE 3 Script for critical appraisal of cohort studies.}

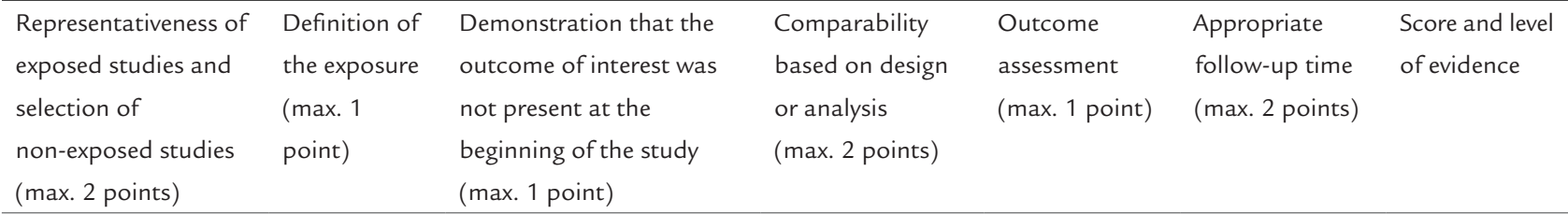

TABLE 4 Description of biases in the selected studies.

\begin{tabular}{lllllllll} 
Study & Question & Randomization & Allocation & Blinding & Losses & Prognosis & Outcomes & ITT analysis \\
\hline Bouchier-Hayes DM 2006 & Yes & No & No & No & Yes $(<20 \%)$ & Yes & Yes & No \\
\hline Horasanli K 2008 & Yes & No & No & No & No & Yes & Yes & No \\
\hline Al-Ansari A 2010 & Yes & Yes & No & No & Yes $(<20 \%)$ & Yes & Yes & Yes \\
\hline Capitán C 2011 & Yes & Yes & Yes & No & Yes $(<20 \%)$ & Yes & Yes & No \\
\hline Mohanty NK 2012 & Yes & No & No & No & Yes $(<20 \%)$ & Yes & Yes & No \\
\hline Lukacs B 2012 & Yes & Yes & Yes & No & Yes $(<20 \%)$ & Yes & Yes & Yes \\
\hline Pereira-Correia JA 2012 & Yes & Yes & No & No & No & Yes & Yes & No \\
\hline Xue B 2013 & Yes & Yes & No & No & No & Yes & Yes & No \\
\hline Jovanović M 2014 & Yes & Yes & No & No & No & Yes & Yes & No \\
\hline Telli O 2015 & Yes & Yes & Yes & No & Yes $(<20 \%)$ & Yes & Yes & No \\
\hline Thomas JA 2016 & Yes & Yes & Yes & No & Yes $(<20 \%)$ & Yes & Yes & No
\end{tabular}


Exposure of results

For results with available evidence, the population, intervention, outcomes, presence or absence of benefit and/ or harm, and controversies will be defined in a specific manner, whenever possible (Table 5).

The results will be preferably expressed in absolute data, absolute risk, number needed to treat (NNT), or number needed to harm (NNH), and occasionally using mean and standard deviation (Tables 6-16).

\section{Recommendation}

The recommendations will be elaborated by the authors of the review, with the initial characteristic of synthesis of the evidence, and later validated by all the authors who participate in the elaboration of this guideline.

The grade of recommendation stems directly from the available strength of included studies, according to the Oxford scale ${ }^{17}$ and the GRADE system. ${ }^{15}$

\section{TABLE 5 Worksheet used to describe and present the results of each study.}

Evidence included

Study design

Population selected

Follow-up time

Outcomes considered

Expression of results: percentages, risk, odds, hazard ratio, mean

\section{TABLE 6 Results of the selected study.}

\section{Bouchier-Hayes DM $2006^{3}$}

\begin{tabular}{llll}
\hline Outcomes & Mean (SD) of the intervention (38) & Mean (SD) of the comparison (38) & Significance \\
\hline Increase in flow (mL/s) & $11.96 \pm 8.23$ & $8.56 \pm 9.08$ & $\mathrm{p}<0.05$ \\
\hline Decline in IPSS & $14.0 \pm 9.8$ & $12.9 \pm 10.6$ & $\mathrm{p}<0.05$ \\
\hline Decline in QoL & $2.65 \pm 2.1$ & $2.91 \pm 2.04$ & $\mathrm{p}<0.05$ \\
\hline Decline in bother score & $1.91 \pm 1.29$ & $1.61 \pm 1.22$ & $\mathrm{p}<0.05$ \\
\hline Post-void residual volume $(\mathrm{mL})$ & $125 \pm 198$ & $86 \pm 124.38$ & $\mathrm{p}<0.05$ \\
\hline Surgical time (min) & $30.24(9-70)$ & $31.33(5-70)$ & $\mathrm{NS}$ \\
\hline Time of irrigation $(\mathrm{min})$ & $12.2 \pm 8.6$ & $44.52 \pm 30.23$ & $\mathrm{p}<0.05$ \\
\hline Time of hospitalization (days) & $1.08 \pm 0.28$ & $3.39 \pm 1.17$ & $\mathrm{p}<0.05$ \\
\hline Decline in hemoglobin levels $(\mathrm{g} / \mathrm{dL})$ & $0.45 \pm 0.7$ & $1.5 \pm 0.15$ & $\mathrm{p}<0.05$ \\
\hline
\end{tabular}

TABLE 7 Results of the selected study.

\begin{tabular}{|c|c|c|c|c|c|c|c|}
\hline Outcomes (6 months) & \multicolumn{2}{|l|}{$\begin{array}{l}\text { Mean (SD) of the } \\
\text { intervention (39) }\end{array}$} & \multicolumn{2}{|l|}{$\begin{array}{l}\text { Mean (SD) of the } \\
\text { comparison ( } 37)\end{array}$} & \multicolumn{3}{|l|}{ Significance } \\
\hline Urinary flow (mL/s) & $13.3 \pm 7.9$ & & $20.7 \pm 11.3$ & & $p<0.05$ & & \\
\hline IPSS & $13.1 \pm 5.8$ & & $6.4 \pm 7.9$ & & $p<0.05$ & & \\
\hline IIEF-5 & $19 \pm 5.2$ & & $21 \pm 6.8$ & & $p<0.05$ & & \\
\hline Post-void residual volume $(\mathrm{mL})$ & $78.9 \pm 62.1$ & & $22.9 \pm 18.7$ & & $p<0.05$ & & \\
\hline Surgical time (min) & $87 \pm 18.3$ & & $51 \pm 17.2$ & & $p<0.05$ & & \\
\hline Length of catheterization (days) & $1.7 \pm 0.8$ & & $3.9 \pm 1.2$ & & $p<0.05$ & & \\
\hline Length of hospitalization (days) & $2 \pm 0.7$ & & $4.8 \pm 1.2$ & & $p<0.05$ & & \\
\hline Outcome & $\begin{array}{l}\text { No. of events } \\
\text { intervention (39) }\end{array}$ & $\begin{array}{l}\text { No. of events } \\
\text { control (37) }\end{array}$ & $\begin{array}{l}\text { Risk } \\
\text { intervention \% }\end{array}$ & $\begin{array}{l}\text { Risk } \\
\text { control \% }\end{array}$ & $\begin{array}{l}\text { Reduction } \\
\text { increase \% }\end{array}$ & $95 \mathrm{Cl}$ & $\begin{array}{l}\text { NNT/ } \\
\text { NNH }\end{array}$ \\
\hline Urinary retention & 6 & 1 & 15.3 & 2.7 & $12.6(\mathrm{ARI})$ & $\begin{array}{l}0.21 \text { to } \\
25.15\end{array}$ & $8(\mathrm{NNH})$ \\
\hline Transfusion & 0 & 3 & 0 & 8.1 & 8.1 (ARR) & NS & NS \\
\hline Re-intervention & 7 & 0 & 17.9 & 0 & $17.9(\mathrm{ARI})$ & $\begin{array}{l}5.90 \text { to } \\
29.99\end{array}$ & $6(\mathrm{NNH})$ \\
\hline
\end{tabular}


TABLE 8 Results of the selected study.

\begin{tabular}{|c|c|c|c|c|c|c|c|}
\hline Outcomes & \multicolumn{2}{|c|}{ Mean (SD) of the intervention (60) } & \multicolumn{3}{|c|}{ Mean (SD) of the comparison (60) } & \multicolumn{2}{|c|}{ Significance } \\
\hline Urinary flow (mL/s) & NS & & NS & & & NS & \\
\hline IPSS & NS & & NS & & & NS & \\
\hline Hemoglobin (intraoperative) & $13.1 \pm 1.5$ & & $11.3 \pm 1.9$ & & & $\mathrm{p}<0.05$ & \\
\hline Post-void residual volume (mL) & NS & & NS & & & NS & \\
\hline Prostatic volume & NS & & NS & & & NS & \\
\hline Surgical time (min) & $89 \pm 18$ & & $80 \pm 13$ & & & $\mathrm{p}<0.05$ & \\
\hline Length of catheterization (days) & $1.4 \pm 0.6$ & & $2.7 \pm 0.9$ & & & $\mathrm{p}<0.05$ & \\
\hline Length of hospitalization (days) & $2.3 \pm 1.2$ & & $4.1 \pm 0.6$ & & & $\mathrm{p}<0.05$ & \\
\hline Outcome & $\begin{array}{l}\text { No. of events } \\
\text { intervention (60) }\end{array}$ & $\begin{array}{l}\text { No. of events } \\
\text { control }(60)\end{array}$ & $\begin{array}{l}\text { Risk } \\
\text { intervention \% }\end{array}$ & $\begin{array}{l}\text { Risk } \\
\text { control \% }\end{array}$ & $\begin{array}{l}\text { Reduction } \\
\text { increase \% }\end{array}$ & $95 \mathrm{Cl}$ & $\begin{array}{l}\text { NNT/ } \\
\text { NNH }\end{array}$ \\
\hline Transfusion & 0 & 12 & 0 & 17.95 & 17.95 (ARR) & $\begin{array}{l}5.90 \text { to } \\
29.99\end{array}$ & 6 (NNT) \\
\hline Intraoperative complications & 0 & 13 & 0 & 20 & 20 (ARR) & $\begin{array}{l}9.87 \text { to } \\
30.12\end{array}$ & 5 (NNT) \\
\hline Early complications & 56 & 19 & 93.33 & 31.67 & $61.67(\mathrm{ARI})$ & $\begin{array}{l}48.31 \text { to } \\
75.02\end{array}$ & $2(\mathrm{NNH})$ \\
\hline Late complications & 10 & 3 & 16.67 & 5 & 11.67 (ARI) & $\begin{array}{l}0.74 \text { to } \\
22.59\end{array}$ & $8(\mathrm{NNH})$ \\
\hline
\end{tabular}

TABLE 9 Results of the selected study.

\section{Capitán C $2011^{6}$}

\begin{tabular}{|c|c|c|c|c|c|c|c|}
\hline Outcomes & \multicolumn{2}{|c|}{ Mean (SD) of the intervention (50) } & \multicolumn{3}{|c|}{ Mean (SD) of the comparison (50) } & \multicolumn{2}{|c|}{ Significance } \\
\hline Urinary flow (mL/s) & 22.56 & & 21.98 & & & NS & \\
\hline IPSS & 8 & & 8.57 & & & NS & \\
\hline Decline in hemoglobin levels $(\mathrm{g} / \mathrm{dL})$ & $0.65 \pm 1.31$ & & $2.30 \pm 4.36$ & & & $\mathrm{p}<0.05$ & \\
\hline Prostatic volume & 27.17 & & 23.8 & & & NS & \\
\hline Surgical time (min) & $54.13 \pm 14.40$ & & $48.15 \pm 14.71$ & & & $\mathrm{p}<0.05$ & \\
\hline Length of catheterization $(\mathrm{h})$ & $23 \pm 22$ & & $72 \pm 48$ & & & $\mathrm{p}<0.05$ & \\
\hline Length of hospitalization (days) & $1.6(1-5)$ & & $3.6 \pm 2.1$ & & & $\mathrm{p}<0.05$ & \\
\hline Outcome & $\begin{array}{l}\text { No. of events } \\
\text { intervention ( } 50)\end{array}$ & $\begin{array}{l}\text { No. of events } \\
\text { control (50) }\end{array}$ & $\begin{array}{l}\text { Risk } \\
\text { intervention \% }\end{array}$ & $\begin{array}{l}\text { Risk } \\
\text { control \% }\end{array}$ & $\begin{array}{l}\text { Reduction } \\
\text { increase \% }\end{array}$ & $95 \mathrm{Cl}$ & $\begin{array}{l}\text { NNT/ } \\
\text { NNH }\end{array}$ \\
\hline Cateter $<20 \mathrm{~F}$ & 50 & 8 & 100 & 16 & $84($ ARR) & $\begin{array}{l}73.94 \text { to } \\
94.16\end{array}$ & $\begin{array}{l}1 \\
(\mathrm{NNT})\end{array}$ \\
\hline Intraoperative complications & 0 & 5 & 0 & 10 & $10(\mathrm{ARR})$ & $\begin{array}{l}1.68 \text { to } \\
18.31\end{array}$ & $\begin{array}{l}10 \\
\text { (NNT) }\end{array}$ \\
\hline Early complications & 14 & 8 & 28 & 16 & NS & NS & NS \\
\hline Late complications & 7 & 16 & 14 & 32 & 18 (ARR) & $\begin{array}{l}1.8 \text { to } \\
34.11\end{array}$ & $\begin{array}{l}6 \\
(\mathrm{NNT})\end{array}$ \\
\hline
\end{tabular}


TABLE 10 Results of the selected study.

Lukacs B $2012^{7}$

\begin{tabular}{|c|c|c|c|c|c|c|c|}
\hline Outcomes - 12 months & $\begin{array}{l}\text { Mean (SD) of the } \\
\text { intervention (69) }\end{array}$ & & & $\begin{array}{l}\text { Mean (SD) } \\
\text { comparisor }\end{array}$ & $\begin{array}{l}\text { f the } \\
70)\end{array}$ & Signif & cance \\
\hline QoL & $75(60-85)$ & & & $77(69.5-87.5$ & & NS & \\
\hline IPSS & $6.26(3.23-9.30)$ & & & $7.94(4.9-10$. & & NS & \\
\hline Urinary flow $(\mathrm{mL} / \mathrm{s})$ & $16.7(12-22.7)$ & & & $16.8(12.1-2$ & & NS & \\
\hline PVRV & $7(0-32)$ & & & $0(0-43)$ & & NS & \\
\hline Prostatic volume & $30(22-40)$ & & & $24.7(18.5-3$ & & NS & \\
\hline Sexual satisfaction & $2(1-4)$ & & & $2(1-4)$ & & NS & \\
\hline Surgical time (min) & $55(45-65)$ & & & $71(55-95)$ & & $p<0.05$ & \\
\hline Length of hospitalization (days) & $2.5(2-3.5)$ & & & $1(1-2)$ & & $p<0.05$ & \\
\hline Outcome & $\begin{array}{l}\text { No. of events } \\
\text { intervention (69) }\end{array}$ & $\begin{array}{l}\text { No. of events } \\
\text { control (70) }\end{array}$ & $\begin{array}{l}\text { Risk } \\
\text { intervention \% }\end{array}$ & $\begin{array}{l}\text { Risk } \\
\text { control \% }\end{array}$ & $\begin{array}{l}\text { Reduction } \\
\text { increase \% }\end{array}$ & $95 \mathrm{Cl}$ & $\begin{array}{l}\text { NNT/ } \\
\text { NNH }\end{array}$ \\
\hline Complications & 18 & 27 & 26.5 & 39.7 & NS & NS & NS \\
\hline
\end{tabular}

TABLE 11 Results of the selected study.

Mohanty NK $2012^{8}$

\begin{tabular}{|c|c|c|c|c|c|c|c|}
\hline Outcomes - 12 months & \multicolumn{2}{|c|}{ Mean (SD) of the intervention (52) } & \multicolumn{3}{|c|}{ Mean (SD) of the comparison (50) } & \multicolumn{2}{|c|}{ Significance } \\
\hline QoL & $1.52 \pm 0.50$ & & $1.48 \pm 0.50$ & & & NS & \\
\hline IPSS & $5.96 \pm 1.98$ & & $6.00 \pm 1.95$ & & & NS & \\
\hline Urinary flow (mL/s) & $20.12 \pm 3.99$ & & $19.77 \pm 3.12$ & & & NS & \\
\hline PVRV & $23.94 \pm 13.26$ & & $20.40 \pm 12.73$ & & & NS & \\
\hline Prostatic volume & $26.27 \pm 7.35$ & & $26.0 \pm 8.88$ & & & NS & \\
\hline Hemoglobin (g/dL) & $12.42 \pm 1.32$ & & $11.16 \pm 1.31$ & & & $\mathrm{p}<0.05$ & \\
\hline Surgical time ( $\mathrm{min})$ & $53.72 \pm 10.23$ & & $42.77 \pm 12.93$ & & & $\mathrm{p}<0.05$ & \\
\hline Length of catheterization $(h)$ & $24.65 \pm 2.98$ & & $49.23 \pm 14.17$ & & & $p<0.05$ & \\
\hline Outcome & $\begin{array}{l}\text { No. of events } \\
\text { intervention (60) }\end{array}$ & $\begin{array}{l}\text { No. of events } \\
\text { control (57) }\end{array}$ & $\begin{array}{l}\text { Risk } \\
\text { intervention \% }\end{array}$ & $\begin{array}{l}\text { Risk } \\
\text { control \% }\end{array}$ & $\begin{array}{l}\text { Reduction } \\
\text { increase \% }\end{array}$ & $95 \mathrm{Cl}$ & $\begin{array}{l}\text { NNT/ } \\
\text { NNH }\end{array}$ \\
\hline Complications & 26 & 28 & 43.33 & 49.12 & NS & NS & NS \\
\hline
\end{tabular}

TABLE 12 Results of the selected study.

\section{Pereira-Correia JA $2012^{9}$}

\begin{tabular}{llll}
\hline Outcomes $-\mathbf{1 2}$ months & Mean (SD) of the intervention (10) & Mean (SD) of the comparison (10) & Significance \\
\hline ICIQ-SF & $0(0)$ & $0(0)$ & NS \\
\hline IIEF-5 & $23(22-24)$ & $23(22-24)$ & NS \\
\hline IPSS & $6(2-10)$ & $6(1-12)$ & NS \\
\hline Urinary flow $(\mathrm{mL} / \mathrm{s})$ & $22.2(12-38)$ & $18(10-28)$ & $\mathrm{NS}$ \\
\hline PVRV & $2(0-10)$ & $2.5(0-20)$ & $\mathrm{NS}$ \\
\hline BOOI & $-12(-4$ to -68$)$ & $-1.2(-4$ to -14$)$ & $\mathrm{P}<0.05$
\end{tabular}


TABLE 13 Results of the selected study.

Xue B 2013 ${ }^{10}$

\begin{tabular}{|c|c|c|c|c|c|c|c|}
\hline Outcomes - 24 months & \multicolumn{2}{|c|}{ Mean (SD) of the intervention (100) } & \multicolumn{3}{|c|}{ Mean (SD) of the comparison (100) } & \multicolumn{2}{|c|}{ Significance } \\
\hline QoL & 1 & & 1.2 & & & NS & \\
\hline IPSS & 10.4 & & 9.1 & & & NS & \\
\hline Urinary flow (mL/s) & 19.6 & & 20.9 & & & NS & \\
\hline $\operatorname{PVRV}(\mathrm{mL})$ & 14.4 & & 15.7 & & & NS & \\
\hline Prostatic volume & 33.8 & & 23.8 & & & $\mathrm{p}<0.05$ & \\
\hline Hemoglobin & $13.9 \pm 1.8$ & & $12.1 \pm 1.6$ & & & NS & \\
\hline Surgical time & $52.3 \pm 15.4$ & & $47.6 \pm 14.2$ & & & $\mathrm{p}<0.05$ & \\
\hline Length of catheterization & $1.9 \pm 0.8$ & & $3.6 \pm 1.7$ & & & $\mathrm{p}<0.05$ & \\
\hline Length of hospitalization & $4.3 \pm 1.5$ & & $6.8 \pm 2.1$ & & & $\mathrm{p}<0.05$ & \\
\hline Outcome & $\begin{array}{l}\text { No. of events } \\
\text { intervention (100) }\end{array}$ & $\begin{array}{l}\text { No. of events } \\
\text { control (100) }\end{array}$ & $\begin{array}{l}\text { Risk } \\
\text { intervention \% }\end{array}$ & $\begin{array}{l}\text { Risk } \\
\text { control \% }\end{array}$ & $\begin{array}{l}\text { Reduction } \\
\text { increase \% }\end{array}$ & $95 \mathrm{Cl}$ & $\begin{array}{l}\text { NNT/ } \\
\text { NNH }\end{array}$ \\
\hline Transfusion & 0 & 4 & 0 & 4 & 4 (ARR) & 0.15 to 7.8 & 25 \\
\hline TURP syndrome & 0 & 0 & 0 & 0 & NS & NS & NS \\
\hline Perforation & 0 & 5 & 0 & 5 & 5 (ARR) & 0.7 to 9.2 & 20 \\
\hline Infection & 4 & 5 & 0 & 5 & NS & NS & NS \\
\hline Dysuria & 9 & 8 & 9 & 8 & NS & NS & NS \\
\hline Incontinence & 3 & 4 & 3 & 4 & NS & NS & NS \\
\hline Urethral stricture & 5 & 2 & 5 & 2 & NS & NS & NS \\
\hline Re-intervention & 4 & 1 & 4 & 1 & NS & NS & NS \\
\hline
\end{tabular}

\section{TABLE 14 Results of the selected study.}

Jovanović M 2014 ${ }^{11}$

\begin{tabular}{|c|c|c|c|c|c|c|c|}
\hline Outcomes - 12 months & \multicolumn{2}{|c|}{ Mean (SD) of the intervention (31) } & \multicolumn{3}{|c|}{ Mean (SD) of the comparison (31) } & \multicolumn{2}{|l|}{ Significance } \\
\hline IPSS & 5.2 & & 4.8 & & & NS & \\
\hline Urinary flow (mL/s) & 18.7 & & 18.5 & & & NS & \\
\hline Surgical time & $92 \pm 18$ & & $82 \pm 13$ & & & $\mathrm{p}<0.05$ & \\
\hline Length of hospitalization & $1.9 \pm 0.8$ & & $4.4 \pm 0.6$ & & & $\mathrm{p}<0.05$ & \\
\hline Hemoglobin & $13.2 \pm 1.5$ & & $11.7 \pm 1.9$ & & & NS & \\
\hline Length of catheterization & $1.1 \pm 0.6$ & & $2.9 \pm 0.9$ & & & $\mathrm{p}<0.05$ & \\
\hline Outcome & $\begin{array}{l}\text { No. of events } \\
\text { ntervention ( } 31 \text { ) }\end{array}$ & $\begin{array}{l}\text { No. of events } \\
\text { control (31) }\end{array}$ & $\begin{array}{l}\text { Risk } \\
\text { intervention \% }\end{array}$ & $\begin{array}{l}\text { Risk } \\
\text { control \% }\end{array}$ & $\begin{array}{l}\text { Reduction } \\
\text { increase \% }\end{array}$ & $95 \mathrm{Cl}$ & $\begin{array}{l}\text { NNT/ } \\
\text { NNH }\end{array}$ \\
\hline Transfusion & 0 & 6 & 0 & 19.4 & 19.4 (ARR) & 5.4 to 33.2 & 5 \\
\hline Clot retention & 0 & 2 & 0 & 6.4 & NS & NS & NS \\
\hline Urethral stricture & 1 & 4 & 3.2 & 12.9 & NS & NS & NS \\
\hline Perforation & 0 & 5 & 0 & 16.1 & 16.1 (ARR) & 3.1 to 29.0 & 6 \\
\hline Dysuria/urgency & 9 & 10 & 29 & 32.2 & NS & NS & NS \\
\hline TURP syndrome & 0 & 1 & 0 & 3.1 & NS & NS & NS \\
\hline
\end{tabular}


TABLE 15 Results of the selected study.

Telli O $2015^{12}$

\begin{tabular}{|c|c|c|c|c|c|c|c|}
\hline Outcomes - 24 months & \multicolumn{2}{|c|}{ Mean (SD) of the intervention (39) } & \multicolumn{3}{|c|}{ Mean (SD) of the comparison (62) } & \multicolumn{2}{|c|}{ Significance } \\
\hline IPSS & $75(30-92)$ & & $60(37-91)$ & & & NS & \\
\hline Urinary flow (mL/s) & $22.6 \pm 0.9$ & & $24.5 \pm 1.2$ & & & NS & \\
\hline $\operatorname{PVRV}(\mathrm{mL})$ & $60(13-88)$ & & $58(95-100)$ & & & NS & \\
\hline Sexual activity (SHIM score) & $32(27-41)$ & & $34(25-46)$ & & & NS & \\
\hline Prostatic volume & $23.9 \pm 13$ & & $22.4 \pm 13.3$ & & & NS & \\
\hline Length of hospitalization & $2(1-4)$ & & $5(3-9)$ & & & $\mathrm{p}<0.05$ & \\
\hline Outcome & $\begin{array}{l}\text { No. of events } \\
\text { intervention (60) }\end{array}$ & $\begin{array}{l}\text { No. of events } \\
\text { control (64) }\end{array}$ & $\begin{array}{l}\text { Risk } \\
\text { intervention \% }\end{array}$ & $\begin{array}{l}\text { Risk } \\
\text { control \% }\end{array}$ & $\begin{array}{l}\text { Reduction } \\
\text { increase \% }\end{array}$ & $95 \mathrm{Cl}$ & $\begin{array}{l}\text { NNT/ } \\
\text { NNH }\end{array}$ \\
\hline Transfusion & 2 & 2 & 3.33 & 3.12 & NS & NS & NS \\
\hline Urinary retention & 3 & 4 & 4.68 & 6.66 & NS & NS & NS \\
\hline Urethral stricture & 5 & 12 & 8.33 & 18.75 & NS & NS & NS \\
\hline Re-intervention & 2 & 4 & 3.33 & 6.25 & NS & NS & NS \\
\hline Infection & 4 & 6 & 6.66 & 9.37 & NS & NS & NS \\
\hline
\end{tabular}

TABLE 16 Results of the selected study.

Thomas JA $2016^{13}$

\begin{tabular}{|c|c|c|c|c|c|c|c|}
\hline Outcomes - 24 months & \multicolumn{2}{|c|}{ Mean (SD) of the intervention (128) } & \multicolumn{3}{|c|}{ Mean (SD) of the comparison (121) } & \multicolumn{2}{|c|}{ Significance } \\
\hline QoL & $1.3 \pm 1.2$ & & $1.2 \pm 1.3$ & & & NS & \\
\hline IIEF-5 & $12.9 \pm 7.5$ & & $13.9 \pm 8.2$ & & & NS & \\
\hline IPSS & $9.5 \pm 3.0$ & & $9.9 \pm 3.5$ & & & NS & \\
\hline Urinary flow (mL/s) & $21.6 \pm 10.7$ & & $22.9 \pm 9.3$ & & & NS & \\
\hline PVRV (mL) & $45.6 \pm 65.5$ & & $34.9 \pm 47.1$ & & & NS & \\
\hline Prostatic volume & $23.9 \pm 13$ & & $22.4 \pm 13.3$ & & & NS & \\
\hline Outcome & $\begin{array}{l}\text { No. Of events } \\
\text { intervention (139) }\end{array}$ & $\begin{array}{l}\text { No. Of events } \\
\text { control (142) }\end{array}$ & $\begin{array}{l}\text { Risk } \\
\text { intervention \% }\end{array}$ & $\begin{array}{l}\text { Risk } \\
\text { control \% }\end{array}$ & $\begin{array}{l}\text { Reduction } \\
\text { increase \% }\end{array}$ & $95 \mathrm{Cl}$ & $\begin{array}{l}\text { NNT/ } \\
\text { NNH }\end{array}$ \\
\hline Re-treatment & 78 & 73 & 56.12 & 51.41 & NS & NS & NS \\
\hline Complication-free & 116 & 112 & 83.45 & 78.87 & NS & NS & NS \\
\hline
\end{tabular}

